\title{
An Evaluation of the Accuracy and Precision of a Stand-Alone Submersible Continuous Ruminal pH Measurement System ${ }^{1}$
}

\author{
G. B. Penner, ${ }^{\star} \dagger$ K. A. Beauchemin, $\dagger^{2}$ and T. Mutsvangwa* \\ *Department of Animal and Poultry Science, University of Saskatchewan, Saskatoon, S7N 5A8, Canada \\ †Agriculture and Agri-Food Canada, Research Centre, Lethbridge, Alberta, T1J 4B1, Canada
}

\begin{abstract}
The objectives of this study were 1) to develop and evaluate the accuracy and precision of a new standalone submersible continuous ruminal $\mathrm{pH}$ measurement system called the Lethbridge Research Centre ruminal $\mathrm{pH}$ measurement system ( $\mathrm{LRCpH}$; Experiment 1);2) to establish the accuracy and precision of a welldocumented, previously used continuous indwelling ruminal $\mathrm{pH}$ system $(\mathrm{CIpH})$ to ensure that the new system $(\mathrm{LRCpH})$ was as accurate and precise as the previous system (CIpH; Experiment 2); and 3) to determine the required frequency for $\mathrm{pH}$ electrode standardization by comparing baseline millivolt readings of $\mathrm{pH}$ electrodes in $\mathrm{pH}$ buffers 4 and 7 after $0,24,48$, and $72 \mathrm{~h}$ of ruminal incubation (Experiment 3). In Experiment 1, 6 pregnant Holstein heifers, 3 lactating, primiparous Holstein cows, and 2 Black Angus heifers were used. All experimental animals were fitted with permanent ruminal cannulas. In Experiment 2, the 3 cannulated, lactating, primiparous Holstein cows were used. In both experiments, ruminal $\mathrm{pH}$ was determined continuously using indwelling $\mathrm{pH}$ electrodes. Subsequently, mean $\mathrm{pH}$ values were then compared with ruminal $\mathrm{pH}$ values obtained using spot samples of ruminal fluid (MANpH) obtained at the same time. A correlation coefficient accounting for repeated measures was calculated and results were used to calculate the concordance correlation to examine the relationships between the $\mathrm{LRCpH}$-derived values and $\mathrm{MANpH}$, and the $\mathrm{CIpH}$-derived values and MANpH. In Experiment 3, the 6 pregnant Holstein heifers were used along with 6 new submersible $\mathrm{pH}$ electrodes. In Experiments 1 and 2, the comparison of the LRCpH output (1- and 5-min averages) to $\mathrm{MANpH}$ had higher correlation coefficients after accounting for repeated measures ( 0.98 and 0.97 for 1 - and 5 -min averages, respectively) and concordance correlation coefficients $(0.96$ and 0.97 for 1 - and 5 -min averages, respectively) than the comparison of $\mathrm{CIpH}$ to $\mathrm{MANpH}$ (0.88
\end{abstract}

Received August 12, 2005.

Accepted January 26, 2006.

${ }^{1}$ Contribution number: (387) 05041.

${ }^{2}$ Corresponding author: beauchemin@agr.gc.ca and 0.87 , correlation coefficient and concordance correlation coefficient, respectively). The concordance correlation analysis indicated that the ruminal $\mathrm{pH}$ data for $\mathrm{LRCpH}$ (1- and 5-min averages) vs. $\mathrm{MANpH}$ had location shifts that were smaller than those of the $\mathrm{CIpH}$ vs. MANpH. However, the scale shift was similar between the $\mathrm{LRCpH}$ and the $\mathrm{CIpH}$. The plotted data from both systems closely resembled the line $\mathrm{y}=\mathrm{x}$, indicating that both systems were accurate and precise. In Experiment 3 , changes in baseline millivolt readings for $\mathrm{pH}$ readings after 24,48 , or $72 \mathrm{~h}$ of ruminal incubation were not significantly different than zero, indicating that daily standardization of new electrodes was not essential. Results from this study indicate that the $\mathrm{LRCpH}$ system can accurately and precisely measure ruminal $\mathrm{pH}$; thus, it provides increased opportunity for researchers to measure ruminal $\mathrm{pH}$ and the occurrence of ruminal acidosis in unrestrained cattle.

Key words: ruminal $\mathrm{pH}$, indwelling ruminal $\mathrm{pH}$ probe, acidosis, dairy cow

\section{INTRODUCTION}

Ruminal acidosis is a common problem in modern ruminant production, particularly in high-producing dairy herds (Nocek, 1997) as the demands for increased milk production have resulted in high-grain, low-fiber diets being the norm to maximize energy intake. Feeding high-grain diets can result in a decrease in ruminal $\mathrm{pH}$ due to the ruminal accumulation of VFA and, to a smaller extent, lactate; thus, resulting in acute or subacute ruminal acidosis (Owens et al., 1998). Dairy cows experiencing ruminal acidosis will exhibit a range of clinical symptoms including decreased milk production, intermittent diarrhea, and laminitis (Underwood, 1992; Nocek, 1997). Measurement of ruminal fluid $\mathrm{pH}$ is a reliable and accurate diagnostic test for ruminal acidosis. For this reason, various techniques are available for measuring ruminal $\mathrm{pH}$ under both experimental and field conditions.

Rumenocentesis and oro-ruminal probes have been used to collect ruminal fluid samples for measurement of ruminal $\mathrm{pH}$ under both experimental and field conditions (Oetzel and Nordlund, 1998; Garrett et al., 1999; 
Duffield et al., 2004). However, the usefulness of rumenocentesis in research studies is limited. Furthermore, the risk of peritonitis even with adequate surgical preparation may discourage the use of this technique (Keefe and Ogilvie, 1997; Duffield et al., 2004). Alternatively, various oro-ruminal probes are available, notably the one designed by Geishauser (1993); however, ruminal fluid samples collected through oro-ruminal probes are prone to salivary contamination leading to inaccurate ruminal $\mathrm{pH}$ values (Keefe and Ogilvie, 1997; Duffield et al., 2004). Direct ruminal fluid sampling via a ruminal cannula is still a common method for ruminal $\mathrm{pH}$ measurement in controlled research studies (Reis and Combs, 2000; Kononoff et al., 2003; Duffield et al., 2004). However, spot sampling techniques (rumenocentesis, oro-ruminal probes, direct sampling via a ruminal cannula) all have inherent limitations as they only indicate ruminal $\mathrm{pH}$ at one point in time. Additionally, characterizing ruminal $\mathrm{pH}$ variation over time using spot sampling techniques requires regular sampling with short intervals between samples, making it tedious and labor intensive.

Monitoring ruminal $\mathrm{pH}$ has been automated with the advent of continuous indwelling $\mathrm{pH}$ systems (Dado and Allen, 1993). Continuous indwelling systems have provided data allowing improved characterization of postfeeding ruminal $\mathrm{pH}$ variation, which has increased our understanding of the interactions between diet fermentability, meal size, eating behavior, and ruminal pH (Maekawa et al., 2002; Krause and Combs, 2003). Most continuous indwelling $\mathrm{pH}$ systems have inherent limitations because they restrict animal mobility and, thus, application is limited to tethered animals (Dado and Allen, 1993; Krause and Combs, 2003; Bevans et al., 2005). Recently, several stand-alone systems have been developed (Enemark et al., 2003; Graf et al., 2005). These stand-alone systems continuously measure reticular or ruminal $\mathrm{pH}$ without the use of external cables, thereby allowing the measurement of ruminal $\mathrm{pH}$ in grazing or loose-housed animals. Although stand-alone ruminal $\mathrm{pH}$ measurement systems have been developed, they are in limited use and a thorough validation of these systems is lacking. Therefore, the objectives of the present study were 1) to develop a stand-alone submersible ruminal $\mathrm{pH}$ measurement system for use in cattle and to evaluate its accuracy and precision by comparing its output to $\mathrm{pH}$ measurement of ruminal fluid samples collected via a ruminal cannula (Experiment 1 ); 2) to compare the stand-alone system to an older, well-documented indwelling ruminal $\mathrm{pH}$ measurement system (Experiment 2); and 3) to determine the required frequency of electrode standardization necessary to minimize changes in baseline millivolt readings between the start and end of the measurement period (Experiment 3).

\section{MATERIALS AND METHODS}

\section{Experiment 1: Design and Evaluation of the Lethbridge Research Centre pH Measurement System}

Animals and Management. Three lactating, primiparous Holstein cows (606 $\pm 34 \mathrm{~kg}$ of BW; $25 \pm 1$ DIM), 6 pregnant Holstein heifers (634 $\pm 92 \mathrm{~kg}$ of BW), and 2 Black Angus, nonpregnant heifers (512 $\pm 7 \mathrm{~kg}$ of BW) were used in this experiment. All animals were fitted with permanent ruminal cannulas. The 3 lactating Holstein cows were offered ad libitum a diet consisting of (DM basis) barley silage (42\%), barley grain (29\%), a protein, mineral, and vitamin supplement (16\%), and alfalfa hay (4\%). The 6 pregnant Holstein heifers were fed ad libitum a diet consisting of (DM basis) barley silage (69\%), a protein, mineral, and vitamin supplement (17\%), grass hay $(12 \%)$, and barley grain (7\%). All diets were fed as a TMR at $1330 \mathrm{~h}$ daily. The 2 Black Angus heifers were offered ad libitum a diet consisting of (DM basis) barley grain (88\%), barley silage (9\%), and a supplement containing minerals and vitamins (3\%). This TMR was fed at $1630 \mathrm{~h}$ daily. The rationale for using 11 experimental animals at different physiological states and fed a wide range of diets was to determine the sensitivity of the Lethbridge Research Centre $\mathrm{pH}$ measurement system (LRCpH) under a wide range of $\mathrm{pH}$ values and ruminal conditions (i.e., rumen size, ruminal mat structure, etc.). Experimental animals were housed in individual tie stalls at the Lethbridge Research Centre. In all experiments, experimental animals were cared for according to the guidelines of the Canadian Council of Animal Care (Ottawa, ON, Canada) and the Lethbridge Research Centre Animal Care Committee approved their use for this study.

Design of the LRCpH. The LRCpH system was developed using a data logger (model M1b-pH-1KRTD, Dascor, Escondido, CA), a 9-V battery, and an electrode cable (model S653-ATC-20-BNC, Sensorex, Garden Grove, CA), which were housed in a watertight capsule constructed of polyvinyl chloride material (Figure 1). The $\mathrm{pH}$ electrode (model S650-CDHF, Sensorex) was covered by a $38-\mathrm{mm}$ diameter shroud with four $25-\mathrm{mm}$ holes, which was designed to allow particle and liquid passage while preventing the electrode from contacting the ruminal epithelium. Two $900-\mathrm{g}$ weights were fastened to the bottom of the electrode shroud to maintain the electrode in the ventral sac of the rumen. A $30-\mathrm{cm}$ polyester cable was connected to the capsule and the ruminal cannula plug to aid in system location within 


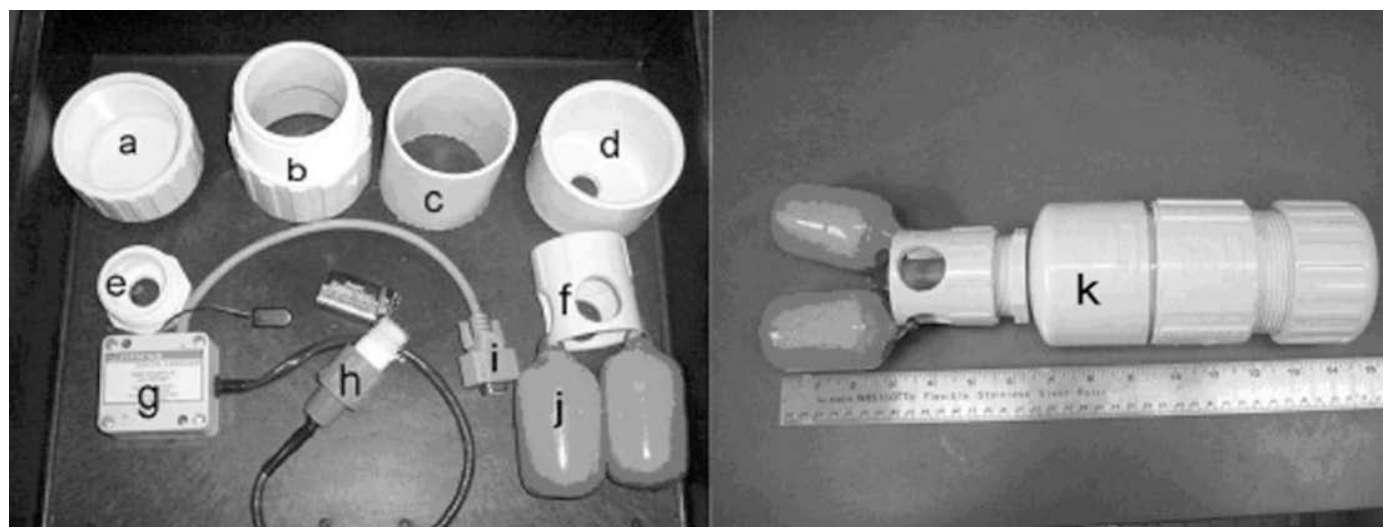

Figure 1. Illustration of the Lethbridge Research Centre ruminal $\mathrm{pH}$ measurement system (LRCpH) in unassembled and assembled forms: $\mathrm{a}=$ threaded cap; $\mathrm{b}=$ male adapter; $\mathrm{c}=$ pipe; $\mathrm{d}=$ slip cap; $\mathrm{e}=$ adapter; $\mathrm{f}=$ electrode shroud; $\mathrm{g}=$ data logger and $\mathrm{pH}$ meter; $\mathrm{h}=$ electrode sensor cable; $\mathrm{i}=$ computer interface cable; $\mathrm{j}=900$-g weight; and $\mathrm{k}=$ assembled LRCpH system.

the rumen and to help maintain the electrode in a vertical position.

Measurement of Ruminal pH. With the $\mathrm{LRCpH}$ system, ruminal $\mathrm{pH}$ was monitored continuously for 24 $\mathrm{h}$ during each collection period. Ruminal $\mathrm{pH}$ readings were taken every $30 \mathrm{~s}$ and readings were averaged over 1- and 5-min intervals, and then stored. A 30-s reading interval was used for the $\mathrm{LRCpH}$ system to reduce the amount of memory required for data storage because battery power usage by the data logger increases with memory use. Before measuring ruminal $\mathrm{pH}$, readings from the electrodes were recorded in standard buffers ( $\mathrm{pH} 4$ and 7). Data transfer from the data logger to a computer and standardization of the $\mathrm{pH}$ electrodes were conducted daily around $1230 \mathrm{~h}$. Briefly, the LRCpH was removed from the rumen, and the $\mathrm{pH}$ electrode was then washed in water at $39^{\circ} \mathrm{C}$, and millivolt readings were recorded in $\mathrm{pH} 4$ and 7 buffer solutions. During this time, $\mathrm{pH}$ electrodes and buffers were maintained at $39^{\circ} \mathrm{C}$ until the data were downloaded and millivolt recordings were taken. The electrodes used have a high thermal mass and maintaining them at $39^{\circ} \mathrm{C}$ reduces the requirement for temperature compensation. The shift in millivolt readings from the electrodes between the start and end standardizations was assumed to be linear and was used to convert millivolt readings to $\mathrm{pH}$ units.

For manual $\mathrm{pH}$ measurement (MANpH), the ruminal cannula plug was opened and a covered $20-\mathrm{mL}$ container was submersed in the rumen contents. Upon submersion, the LRCpH electrode was located within the rumen and ruminal fluid was allowed to fill the container from the immediate location of the $\mathrm{LRCpH}$ electrode. The open end of the container was again covered, removed from the rumen, the ruminal cannula plug was replaced, and ruminal fluid $\mathrm{pH}$ was immedi- ately measured using a portable $\mathrm{pH}$ meter (model IQ150, IQ Scientific Instruments Inc., San Diego, CA) with a glass electrode (model PHE-1411, Omega Engineering, Stamford, CT). The portable $\mathrm{pH}$ meter was calibrated with a 2-point calibration once daily using pH 4 and 7 buffer solutions. Recalibration occurred if readings obtained with $\mathrm{pH}$ buffer solutions were not within $0.02 \mathrm{pH}$ units. The time of ruminal fluid collection was recorded to compare the $\mathrm{MANpH}$ method to results obtained from corresponding $\mathrm{LRCpH}$ measurement. During ruminal fluid collection, positioning of the $\mathrm{LRCpH}$ was noted. Ruminal fluid samples were collected on $4 \mathrm{~d}$ over a 2 -wk duration. On d 1, ruminal fluid samples were collected from the 6 pregnant Holstein heifers every 30 min starting $1 \mathrm{~h}$ postfeeding until $3 \mathrm{~h}$ postfeeding, and sampling commenced again $8 \mathrm{~h}$ postfeeding and ending $10 \mathrm{~h}$ postfeeding. Thus, 66 ruminal fluid samples were collected in total on $\mathrm{d} 1$. On $\mathrm{d}$ 2 , the 3 lactating Holstein cows were sampled every 30 min starting $2.5 \mathrm{~h}$ postfeeding and ending $6.5 \mathrm{~h}$ postfeeding. In total, 21 ruminal fluid samples were collected. On d 3, ruminal fluid was again collected from the 3 lactating Holstein cows. However, 1 cow was omitted from this collection period because her ruminal contents were very dry, which prohibited adequate $\mathrm{LRCpH}$ placement and ruminal $\mathrm{pH}$ measurement. $\mathrm{Ru}-$ minal fluid sampling began $6 \mathrm{~h}$ prefeeding and ended at $0.5 \mathrm{~h}$ prefeeding with samples collected every $30 \mathrm{~min}$, resulting in a total of 24 samples. On d 4, ruminal fluid samples were obtained every 30 min from the 2 Black Angus heifers, starting at $2 \mathrm{~h}$ prefeeding with sampling ending at feeding. Sampling commenced again starting at $2.5 \mathrm{~h}$ postfeeding until $5 \mathrm{~h}$ postfeeding. In total, 20 ruminal fluid samples were collected. Across all experimental animals, a total of 131 ruminal fluid samples were obtained for determination of ruminal $\mathrm{pH}$. 


\section{Experiment 2: Evaluation of a Continuous} Indwelling Ruminal pH Measurement System

Animals and Management. The 3 cannulated, lactating primiparous Holstein cows used in Experiment 1 were used in this experiment. These cows were selected for this experiment because a wide range of ruminal $\mathrm{pH}$ values was measured in these animals during Experiment 1. Diets and feeding management were the same as in Experiment 1.

Design of the Continuous Indwelling Ruminal pH Measurement System. The design and use of the continuous indwelling ruminal $\mathrm{pH}$ measurement system (CIpH) system has been previously documented (see Maekawa et al., 2002; Beauchemin and Yang, 2005; Bevans et al., 2005). Briefly, the CIpH system comprised an industrial microprocessor-based $\mathrm{pH}$ controller (model PHCN-37, Omega Engineering). The pH electrodes (S650-CDHF, Sensorex) were connected to the pH controller with a 9-m cable (PHEH-65-30-ATC, Omega Engineering) suspended above the cows. The cable passed through a ruminal cannula plug and extended approximately $50 \mathrm{~cm}$ into the rumen. The cable was protected from the ruminal environment with a plastic hose. A shroud was constructed around the $\mathrm{pH}$ electrode with four 25-mm holes, which allowed material to percolate through but prevented the electrode from contacting the ruminal epithelium. Two 900-g weights were attached to the electrode shroud to maintain positioning within the ventral sac.

Measurement of Ruminal pH. Continuous measurements of ruminal $\mathrm{pH}$ were collected over 2 consecutive 24-h collection periods using the CIpH. Ruminal $\mathrm{pH}$ was measured every $5 \mathrm{~s}$. For the CIpH system, the 5 -s ruminal $\mathrm{pH}$ readings were averaged over 5-min intervals and recorded by a data logger (model CR10, Campbell Scientific, Logan, UT). Averaging the 5-s pH readings over 5 -min intervals has previously been reported in our laboratory (Beauchemin and Yang, 2005). The 5-min averages corresponded to actual ruminal fluid sampling times used for $\mathrm{MANpH}$ (i.e., when the rumen cannula plug was open) and were used to determine the relationship between $\mathrm{CIpH}$ and $\mathrm{MANpH}$. In this experiment, $\mathrm{pH}$ electrodes were standardized as described for the LRCpH system in Experiment 1.

For manual $\mathrm{pH}$ measurement, ruminal fluid samples were collected using procedures already described in Experiment 1. During ruminal fluid collection, positioning of the $\mathrm{CIpH}$ was noted. Ruminal fluid samples were collected at 30-min intervals over $48 \mathrm{~h}$. In the first 24 $\mathrm{h}$, ruminal fluid samples were collected starting at 5.5 $\mathrm{h}$ prefeeding, ending at $3.5 \mathrm{~h}$ postfeeding, and recommencing at $7 \mathrm{~h}$ postfeeding, and ending at $10 \mathrm{~h}$ postfeeding. During the second 24-h interval, ruminal fluid sam- ples were collected starting at $4.5 \mathrm{~h}$ prefeeding and ending at $1 \mathrm{~h}$ prefeeding. Thus, 32 ruminal fluid samples were collected from each of the 3 cows resulting in a total of 96 data pairs.

\section{Experiment 3: Frequency of Electrode Standardization}

Animals and Management. The 6 cannulated, pregnant Holstein heifers used in Experiment 1 were selected for use in this experiment. Animals were housed individually in tie-stalls. Diets and feeding management were the same as in Experiment 1.

Continuous Measurement of Ruminal pH and Electrode Standardization. Continuous ruminal $\mathrm{pH}$ measurement was conducted using the $\mathrm{LRCpH}$ system as already described. At the beginning of the experiment, 6 new pH electrodes (model S650CD-HF, Sensorex) were installed. In this experiment, $\mathrm{pH}$ electrodes were assigned to a random sequence of 3 treatments: baseline millivolt readings after 24,48 , or $72 \mathrm{~h}$ in the rumen. Millivolt readings in $\mathrm{pH} 4$ and 7 buffer solutions for each $\mathrm{pH}$ electrode were recorded immediately before $\mathrm{pH}$ electrodes were placed into the rumens of experimental animals. Corresponding $\mathrm{pH}$ electrodes were removed from the rumen at 24,48 , or $72 \mathrm{~h}$, and millivolt readings in $\mathrm{pH} 4$ and 7 buffer solutions were again recorded for each $\mathrm{pH}$ electrode. Baseline reading difference was defined as the difference in millivolt readings between the start and end of each treatment duration.

\section{Statistical Analyses}

Experiments 1 and 2. Paired data for ruminal $\mathrm{pH}$ from the $\mathrm{LRCpH}$ (1- and 5-min averages) and $\mathrm{MANpH}$ and from the $\mathrm{CIpH}$ (5-min averages) and $\mathrm{MANpH}$ were analyzed using the MIXED procedure of SAS (version 9.13, SAS Institute, Inc., Cary, NC) with repeated measures to calculate the correlation coefficient (Hamlett et al., 2004). The correlation coefficient was then used to calculate the concordance correlation (Lin, 1989, 1992). Also used in this calculation were the overall mean and variance for each ruminal $\mathrm{pH}$ measurement method. The correlation coefficient calculated to account for repeated measures was used to determine precision by determining the deviation of the data from the best-fit linear line. The concordance correlation coefficient was used to determine accuracy by determining how much the best-fit line deviated from the line $\mathrm{y}=\mathrm{x}$. The data from the experimental method ( $\mathrm{LRCpH}, 1-$ and 5-min averages and $\mathrm{CIpH}, 5$-min averages) were plotted on the $\mathrm{y}$-axis and the data obtained from $\mathrm{MANpH}$ were plotted on the x-axis. Data were also analyzed separately for 2 cows ( 1 with very dry and 1 with very liquid 
ruminal contents) using the same procedures as above. This was conducted to determine if consistency of ruminal contents (due to DM content) had an effect on accuracy and precision.

Experiment 3. To evaluate the frequency required for electrode standardization, the change in baseline millivolt readings between the start and end of each treatment duration was calculated for each electrode. These data were analyzed as a double Latin square design using the MIXED procedure of SAS. The model included the fixed effect of treatment with period and electrode considered random effects. Differences among treatments were compared using Fisher's protected LSD test adjusted with the Tukey-Kramer option. Differences were considered significant at $P<0.05$.

\section{RESULTS AND DISCUSSION}

\section{Experiments 1 and 2: Comparison of the $\mathrm{LRCpH}$ and ClpH Systems to MANpH}

The primary objective of the present study was to develop a stand-alone submersible ruminal $\mathrm{pH}$ measurement system for use in unrestrained cattle and to evaluate its accuracy and precision by comparing its output to $\mathrm{pH}$ measurement of ruminal fluid samples collected via a ruminal cannula. Several other direct methods, including oro-ruminal probes and rumenocentesis, are currently in use for the measurement of ruminal $\mathrm{pH}$; however, the major drawback of these techniques is that they involve spot sampling of ruminal fluid at various intervals and do not yield comprehensive data on postfeeding profiles of ruminal $\mathrm{pH}$. Dado and Allen (1993) originally developed a system for performing continuous measurements of ruminal $\mathrm{pH}$; the major drawback of this system is that the indwelling $\mathrm{pH}$ electrode is directly connected by a cable to a $\mathrm{pH}$ transmitter or computer located next to the cow; thus, animal mobility is restricted and application is limited to tethered animals. The $\mathrm{LRCpH}$ system developed in this study does not require animals to be tethered and provides the capability to measure comprehensive ruminal $\mathrm{pH}$ data.

Relationships between the $\mathrm{LRCpH}$ and $\mathrm{CIpH}$ continuous ruminal $\mathrm{pH}$ measurement systems and manual sampling via the ruminal cannula are shown in Table 1. Because the $\mathrm{CIpH}$ averaged ruminal $\mathrm{pH}$ measurements over 5-min intervals, the $\mathrm{LRCpH}$ ruminal $\mathrm{pH}$ measurements were also averaged over 5-min intervals. This allowed direct comparison of the 2 systems. In addition, ruminal $\mathrm{pH}$ measurements from the $\mathrm{LRCpH}$ were averaged over 1-min intervals to determine if averaging readings over a shortened interval affects accuracy and precision. Overall, mean ruminal $\mathrm{pH}$ values obtained using the $\mathrm{LRCpH}$ (1- and 5-min averages) and the $\mathrm{CIpH}$
Table 1. Relationship between continuous ruminal $\mathrm{pH}$ measurement and manual ruminal $\mathrm{pH}$ measurement using two different continuous ruminal $\mathrm{pH}$ measurement systems $(\mathrm{LRCpH} \text { and } \mathrm{CIpH})^{1}$

\begin{tabular}{|c|c|c|c|}
\hline \multirow[b]{2}{*}{ Variable } & \multicolumn{2}{|c|}{ LRCpH vs. MANpH } & \multirow{2}{*}{$\begin{array}{l}\text { CIpH vs. } \\
\text { MANpH }\end{array}$} \\
\hline & $1-\min ^{2}$ & $5-\min ^{3}$ & \\
\hline Number of data pairs & 131 & 131 & 96 \\
\hline Mean pH (MANpH) & 6.14 & 6.14 & 6.14 \\
\hline Variance & 0.171 & 0.171 & 0.126 \\
\hline Mean $\mathrm{pH}$ (continuous $\mathrm{pH}$ system) & 6.11 & 6.11 & 6.09 \\
\hline Variance & 0.188 & 0.194 & 0.111 \\
\hline Correlation coefficient ${ }^{4}$ & 0.98 & 0.97 & 0.88 \\
\hline Concordance correlation & 0.96 & 0.97 & 0.87 \\
\hline Location shift ${ }^{5}$ & 0.07 & 0.09 & 0.16 \\
\hline Scale shift ${ }^{6}$ & 0.95 & 0.93 & 1.04 \\
\hline
\end{tabular}

${ }^{1} \mathrm{LRCpH}=$ Lethbridge Research Centre ruminal $\mathrm{pH}$ measurement system; $\mathrm{MANpH}=$ manual $\mathrm{pH}$ measurement of rumen fluid samples obtained via a rumen cannula; and $\mathrm{CIpH}=$ continuous indwelling ruminal $\mathrm{pH}$ measurement system.

${ }^{2} \mathrm{LRCpH}$ values were averaged over 1-min intervals corresponding to MANpH.

${ }^{3} \mathrm{LRCpH}$ values were averaged over 5 -min intervals corresponding to MANpH.

${ }^{4}$ Correlation coefficient accounting for repeated measures as described by Hamlett et al. (2004).

${ }^{5}$ Would equal 0 if $\mathrm{y}=\mathrm{x}$.

${ }^{6}$ Would equal 1 if $\mathrm{y}=\mathrm{x}$.

systems were numerically lower $(0.03$ and $0.05 \mathrm{pH}$ units, respectively) when compared with mean ruminal $\mathrm{pH}$ values obtained using the MANpH method (Table 1). In other studies, mean ruminal $\mathrm{pH}$ values were 0.11 $\mathrm{pH}$ units (Dado and Allen, 1993) and 0.06 to $0.18 \mathrm{pH}$ units (Graf et al., 2005) lower when measured using an indwelling $\mathrm{pH}$ electrode system that continuously monitored ruminal $\mathrm{pH}$ compared with direct measurement in ruminal fluid samples obtained via ruminal cannula. With manual sampling of ruminal fluid through the ruminal cannula, there is usually a delay until ruminal fluid $\mathrm{pH}$ is actually measured. Smith (1941) postulated that this delay might allow the escape of $\mathrm{CO}_{2}$ from ruminal fluid samples, thus elevating ruminal fluid $\mathrm{pH}$. In the current study, continuous ruminal $\mathrm{pH}$ measurement occurred while the ruminal cannula plug was open. Thus, the release of carbon dioxide and disruption of the ruminal mat during manual sampling may have increased the values of the continuous measurements. In the current study, the effects of opening the ruminal cannula plug on ruminal fluid $\mathrm{pH}$ were not of concern, because we did not intend to characterize ruminal $\mathrm{pH}$ as a function of diet. Rather, the objective was to evaluate the accuracy and precision of 2 continuous ruminal $\mathrm{pH}$ measurement systems by comparing the output to MANpH. This study confirms results from other laboratories (Dado and Allen, 1993; Graf et al., 2005) indicating that mean $\mathrm{pH}$ from manual sampling methods are higher than mean $\mathrm{pH}$ values obtained from 


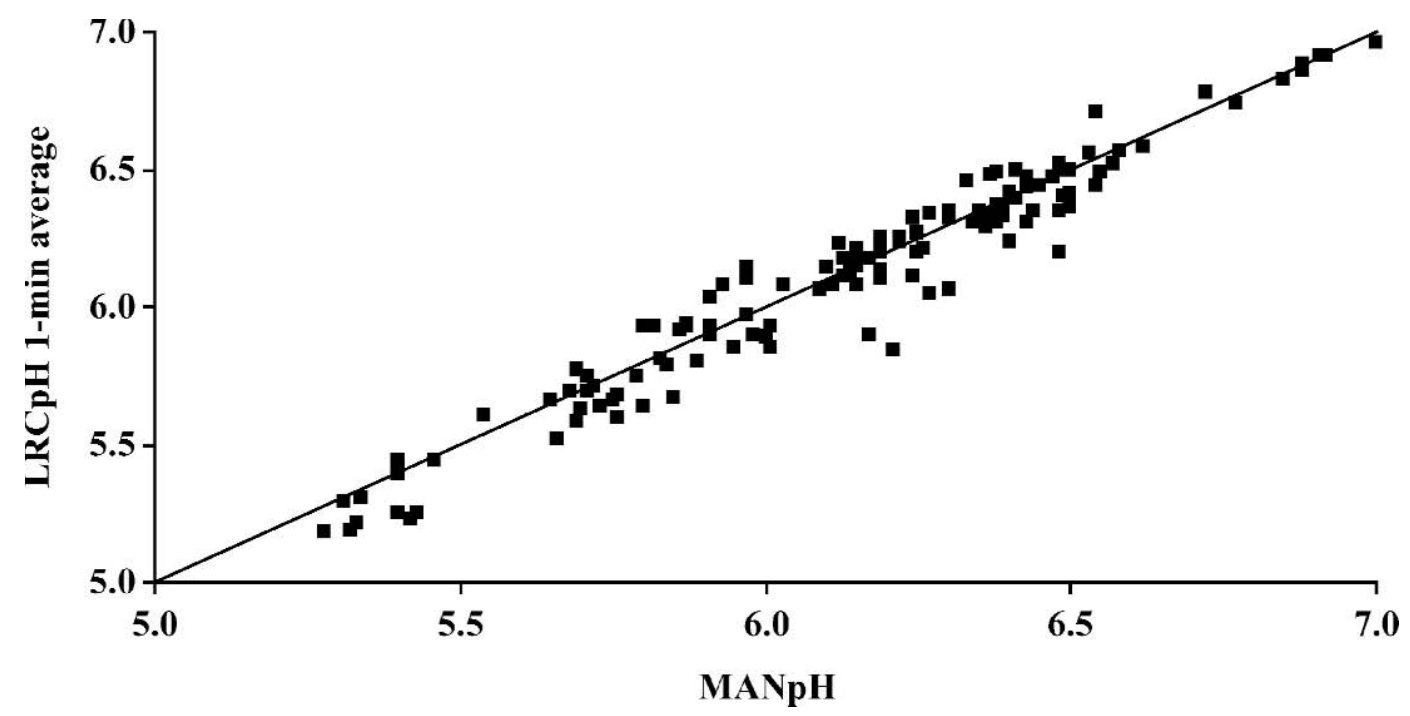

Figure 2. Relationship between ruminal pH determined using ruminal fluid obtained via a ruminal cannula (MANpH) and a submersible continuous ruminal $\mathrm{pH}$ measurement system $(\mathrm{LRCpH})$ when output was averaged over 1-min intervals. The solid line represents the line $\mathrm{y}=\mathrm{x}$.

continuous $\mathrm{pH}$ systems although our mean differences were lower than previously reported values. However, caution should be used when evaluating mean ruminal $\mathrm{pH}$ differences between 2 systems because means indicate very little about the relationship between the 2 methods.

Averaging the LRCpH output over 1- or 5-min intervals did not affect mean $\mathrm{pH}$ (Table 1 ) and, consequently, the correlation coefficient that accounted for repeated measures and concordance correlation coefficients were similar between the LRCpH and MANpH when LRCpH output was averaged over 1 or $5 \mathrm{~min}$. The LRCpH (1and 5-min averages) correlation coefficients that accounted for repeated measures $(0.98$ and 0.97 , respectively) were numerically higher than that calculated for the CIpH (0.88; Table 1). The concordance correlation coefficient was numerically higher for the $\mathrm{LRCpH}$ when compared with the CIpH. Dado and Allen (1993) previously reported a Pearson correlation coefficient of 0.85 for the relationship between a continuous indwelling ruminal $\mathrm{pH}$ measurement system and manual ruminal $\mathrm{pH}$ measurement. The Pearson correlation coefficient indicates how closely the results are related between 2 methods but does not indicate how the plotted data deviates from the line $\mathrm{y}=\mathrm{x}$ (Lin, 1992). Thus, in our study, a correlation coefficient that accounted for repeated measures was used to replace the Pearson correlation coefficient and was also used to calculate the concordance correlation. The repeated measures correlation is used to evaluate precision because it determines the deviation of the data set from the best-fit linear line whereas the concordance correlation is used to evaluate accuracy by determining the deviation of the best-fit linear line to the line $\mathrm{y}=\mathrm{x}$.

To our knowledge, no other studies have reported the correlation coefficient, accounting for repeated measures, or the concordance correlation coefficient when evaluating the accuracy and precision of a continuous ruminal $\mathrm{pH}$ measurement system. The correlation coefficient results from this study suggest that the $\mathrm{LRCpH}$ more closely reflected the $\mathrm{MANpH}$ results than did the $\mathrm{CIpH}$, thus indicating higher accuracy and precision. The improvement in accuracy and precision can be attributed to the design of the system and not the $\mathrm{pH}$ recording interval because the $\mathrm{LRCpH}$ had similar correlation coefficients and concordance correlation coefficients regardless of whether the data were averaged over 1- or 5-min intervals corresponding to ruminal fluid collection time for MANpH (Table 1).

The location shift for the relationship between $\mathrm{LRCpH}$ and $\mathrm{MANpH}$ (0.07 and 0.09 for the 1- and 5-min averages, respectively) was lower than that of CIpH and $\mathrm{MANpH}(0.16)$. The line $\mathrm{y}=\mathrm{x}$ would have a location shift of zero and the location shift indicates how the $y$ intercept of the plotted data differs from the y-intercept of the line $y=x$. Thus, for both systems the $y$-intercept was less than zero indicating that $\mathrm{MANpH}$ results are slightly higher than results from the LRCpH or CIpH. The scale shift was similar for the relationship between the $\mathrm{LRCpH}$ and $\mathrm{MANpH}$ and between the $\mathrm{CIpH}$ and $\mathrm{MANpH}$; however, the shift occurred in opposite directions. The scale shift indicates a discrepancy in slope between the plotted data and the line $\mathrm{y}=\mathrm{x}$. The plotted data for the LRCpH (1- and 5-min averages) vs. 


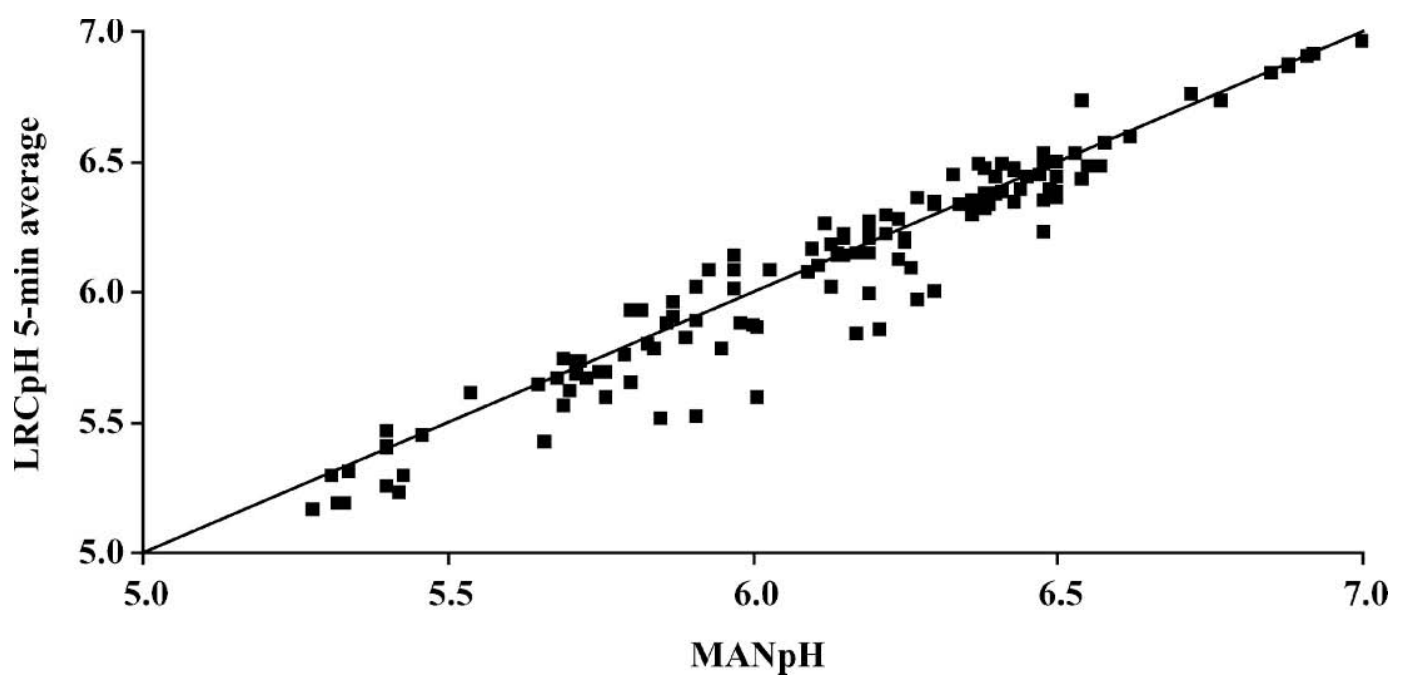

Figure 3. Relationship between ruminal $\mathrm{pH}$ determined using ruminal fluid obtained via a ruminal cannula (MANpH) and a submersible continuous ruminal $\mathrm{pH}$ measurement system $(\mathrm{LRCpH})$ when output was averaged over 5-min intervals. The solid line represents the line $\mathrm{y}=\mathrm{x}$.

$\mathrm{MANpH}$, and $\mathrm{CIpH}$ vs. MANpH appear in Figures 2, 3 , and 4 , respectively.

Other General Observations. It was noted during manual ruminal fluid collection that the $\mathrm{LRCpH}$ did not migrate within the rumen to the same extent as the $\mathrm{CIpH}$ likely because of the design elements; rigid PVC encapsulation, flexible cable fastening to the rumen cannula plug and heavier total weight (two 900-g weights + data logger + PVC capsule). Ruminal conditions can affect the accuracy and precision of the data collected from continuous $\mathrm{pH}$ measurement systems as the $\mathrm{pH}$ electrodes are designed for submersible application and require movement of liquid over the sensor for reliable measurement. We observed that accuracy and precision were numerically reduced when ruminal $\mathrm{pH}$ was measured in an animal observed to have relatively dry ruminal contents when compared with measurement in an animal observed to have relatively fluid ruminal contents. The correlation coefficient, which accounted for repeated measures, and concordance correlation coefficient were 0.75 and 0.74 , respectively, in the animal with dry ruminal contents, and were 0.96

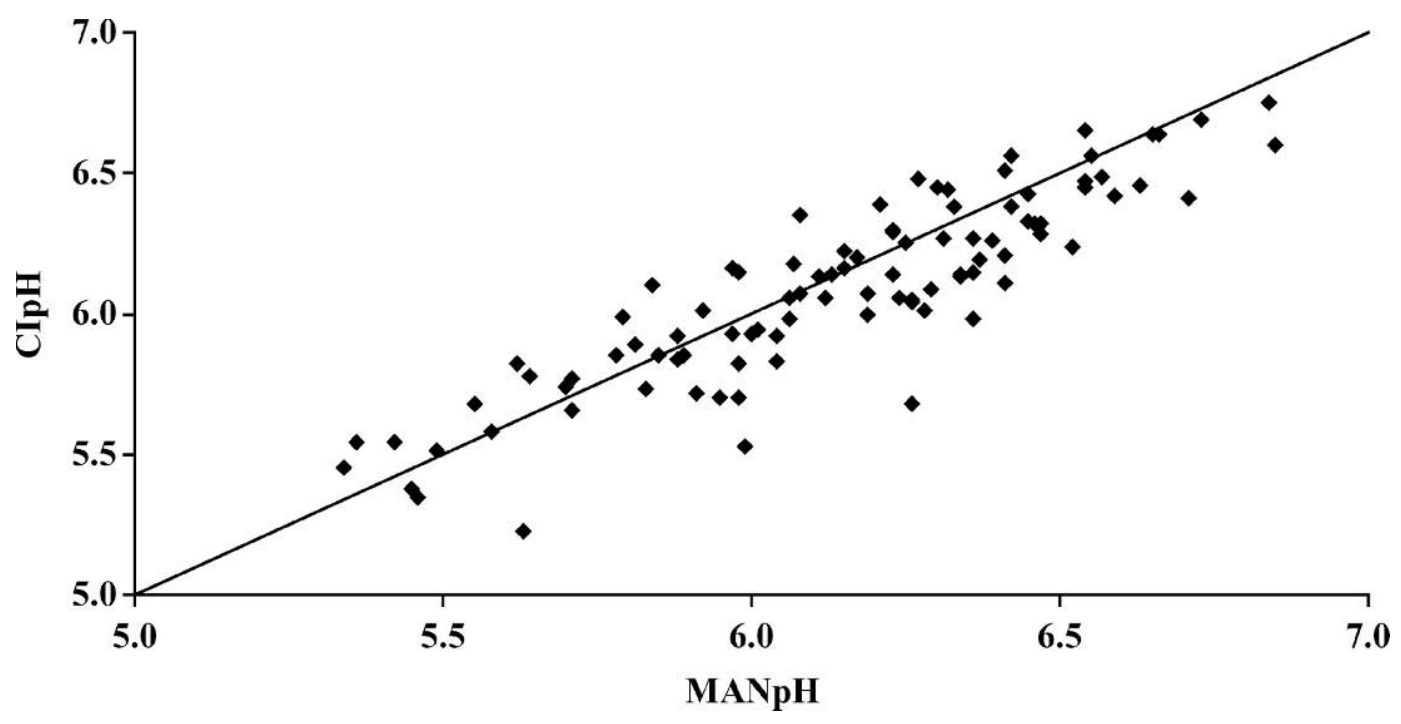

Figure 4. Relationship between ruminal $\mathrm{pH}$ determined using ruminal fluid obtained via a ruminal cannula (MANpH) and using a continuous indwelling $\mathrm{pH}$ measurement system $(\mathrm{CIpH})$. The solid line represents the line $\mathrm{y}=\mathrm{x}$. 
Table 2. Effect of electrode standardization frequency on electrode readings in standard buffers at $\mathrm{pH} 4$ and 7

\begin{tabular}{lrrrrr}
\hline & \multicolumn{3}{c}{ Treatment $^{1}$} & & \\
\cline { 2 - 4 } Variable & R24 & R48 & R72 & SEM & $P$-value \\
\hline Mean baseline reading difference in buffer 4, mV & 2.70 & 4.38 & 4.67 & 4.365 & 0.9425 \\
Difference from zero in buffer 4, $P$-value & 0.55 & 0.33 & 0.30 & & \\
Mean baseline reading difference in buffer 7, $\mathrm{mV}$ & -8.40 & 4.90 & 3.78 & 5.827 & 0.2341 \\
Difference from zero in buffer 7, $P$-value & 0.17 & 0.41 & 0.53 & & \\
\hline
\end{tabular}

${ }^{1} \mathrm{R} 24, \mathrm{R} 48$, and $\mathrm{R} 72$ represent electrodes maintained in the rumen for 24 , 48 , and $72 \mathrm{~h}$, respectively.

and 0.96 , respectively, in the animal with more fluid ruminal contents. This indicates that the system may function less well when used in animals with a lower proportion of ruminal fluid. However, results generated from the entire data set indicate that there were no significant differences in accuracy and precision among animals $(P=0.12)$ or time relative to feeding $(P=0.25)$.

\section{Experiment 3: Frequency of Electrode Standardization}

No electrode failure occurred in the current study. Mean baseline millivolt readings in $\mathrm{pH} 4(P=0.94)$ and $7(P=0.23)$ buffer solutions were not different for $\mathrm{pH}$ electrodes after 24,48 , or $72 \mathrm{~h}$ of ruminal incubation (Table 2). Furthermore, the changes in baseline millivolt readings for all treatments did not differ $(P>0.05)$ from zero (Table 2). However, electrode drift for individual probes did not always occur in the same direction for any of the treatment durations (data not shown). Previously, Nocek et al. (2002) noted a requirement for electrode standardization; however, that study only examined the effect of probe cleansing and standardization on $\mathrm{pH}$ readings after $4,6,8,12$, and $24 \mathrm{~h}$ in the rumen. Enemark et al. (2003) maintained electrodes in the reticulum for $8 \mathrm{~d}$ with minimal electrode drift; however, only 2 electrodes were used. Results from the current study suggest that new electrodes can be maintained in the rumen for at least $72 \mathrm{~h}$ without having a significant impact on millivolt readings. Using millivolt readings to calculate $\mathrm{pH}$ values indicated that the mean error that occurred by not recalibrating electrodes and not correcting data for changes in baseline millivolt readings within a 72-h period was $0.03 \mathrm{pH}$ units. The maximum possible error found in this study between consecutive standardizations was $0.13,0.18$, and 0.10 $\mathrm{pH}$ units after 24,48 , and $72 \mathrm{~h}$ in the rumen, respectively, within a pH range of 4.5 to 7.0. Based on the results of this study, there is no requirement for daily removal and standardization of new electrodes; however, there may be a requirement for regular inspection of electrode function, because malfunction would result in a loss of data. Unlike the CIpH, the $\mathrm{LRCpH}$ does not have a visual display indicating millivolt or $\mathrm{pH}$ readings and electrode failure would not be diagnosed until the time of electrode standardization. More research is required to determine how electrode usage over time influences baseline millivolt reading stability between standardizations. It can be concluded that daily standardization of new electrodes is not required and the duration between consecutive standardizations could be extended to $72 \mathrm{~h}$.

\section{CONCLUSIONS}

Indwelling systems for continually monitoring ruminal $\mathrm{pH}$ provide an accurate means of measuring changes in $\mathrm{pH}$ over time. A new submersible system called the $\mathrm{LRCpH}$ that can be used in feedlots, freestall dairies, or in grazing applications was developed and shown to be highly accurate and precise. Based on results of this study, new electrodes can be continuously maintained in the rumen for at least $72 \mathrm{~h}$ without adverse effects on measurement accuracy. The $\mathrm{LRCpH}$ provides an increased opportunity for researchers to accurately and precisely measure ruminal $\mathrm{pH}$ and the occurrence of ruminal acidosis in unrestrained cattle.

\section{ACKNOWLEDGMENTS}

We gratefully acknowledge Toby Entz for his assistance with statistical analysis and Brian Nishyiama for his assistance with programming. We would also like to thank Chase Wendorff and Bev Farr for their assistance with manual ruminal fluid sampling and continuous $\mathrm{pH}$ measurement.

\section{REFERENCES}

Beauchemin, K. A., and W. Z. Yang. 2005. Effects of physically effective fiber on intake, chewing activity, and ruminal acidosis for dairy cows fed diets based on corn silage. J. Dairy Sci. 88:2117-2129.

Bevans, D. W., K. A. Beauchemin, K. S. Schwartzkopf-Genswein, J. J. McKinnon, and T. A. McAllister. 2005. Effect of rapid or gradual grain adaptation on subacute acidosis and feed intake by feedlot cattle. J. Anim. Sci. 83:1116-1132. 
Dado, R. G., and M. S. Allen. 1993. Continuous computer acquisition of feed and water intakes, chewing, reticular motility, and ruminal pH of cattle. J. Dairy Sci. 76:1589-1600.

Duffield, T., J. C. Plaizier, A. Fairfield, R. Bagg, G. Vessie, P. Dick, J. Wilson, J. Aramini, and B. McBride. 2004. Comparison of techniques for measurement of rumen $\mathrm{pH}$ in lactating dairy cows. J. Dairy Sci. 87:59-66.

Enemark, J. M. D., G. Peters, and R. J. Jorgensen. 2003. Continuous monitoring of rumen $\mathrm{pH}-\mathrm{A}$ case study with cattle. J. Vet. Med. Ser. A. 50:62-66.

Garrett, E. F., M. N. Pereira, K. N. Nordlund, L. E. Armentano, W. J. Goodger, and G. R. Oetzel. 1999. Diagnostic methods for the detection of subacute ruminal acidosis in dairy cows. J. Dairy Sci. 82:1170-1178.

Geishauser, T. 1993. An instrument for the collection and transfer of ruminal fluid and for the administration of water-soluble drugs in adult cattle. Bovine Pract. 27:38-42.

Graf, C. M., M. Kreuzer, and F. Dohme. 2005. Effects of supplemental hay and corn silage versus full-time grazing on ruminal $\mathrm{pH}$ and chewing activity of dairy cows. J. Dairy Sci. 88:711-725.

Hamlett, A., L. Ryan, and R. Wolfinger. 2004. On the use of proc mixed to estimate correlation in the presence of repeated measures. Proc. Statistics and Data Analysis. SAS Users Group International. http://www2.sas.com/proceedings/sugi29/198-29.pdf Accessed Apr. 19, 2006.

Keefe, G. P., and T. H. Ogilvie. 1997. Comparison of oro-ruminal probe and rumenocentesis for prediction of rumen $\mathrm{pH}$ in dairy cattle. Proc. Annu. Conf. Am. Assoc. Bovine Pract. 30:168-169.

Kononoff, P. J., A. J. Heinrichs, and H. A. Lehman. 2003. The effect of corn silage particle size on eating behavior, chewing activities, and rumen fermentation in lactating dairy cows. J. Dairy Sci. 86:3343-3353.

Krause, K. M., and D. K. Combs. 2003. Effects of forage particle size, forage source, and grain fermentability on performance and ruminal pH in midlactation cows. J. Dairy Sci. 86:1382-1397.

Lin, L. I.-K. 1989. A concordance correlation coefficient to evaluate reproducibility. Biometrics 45:255-268.

Lin, L. I.-K. 1992. Assay validation using the concordance correlation coefficient. Biometrics 48:599-604.

Maekawa, M., K. A. Beauchemin, and D. A. Christensen. 2002. Chewing activity, saliva production, and ruminal $\mathrm{pH}$ of primiparous and multiparous lactating dairy cows. J. Dairy Sci. 85:1176-1182.

Nocek, J. E. 1997. Bovine acidosis: Implications on laminitis. J. Dairy Sci. 80:1005-1028.

Nocek, J. E., J. G. Allman, and W. P. Kautz. 2002. Evaluation of an indwelling ruminal probe methodology and effect of grain level on diurnal pH variation in dairy cattle. J. Dairy Sci. 85:422-428.

Oetzel, G. R., and K. V. Nordlund. 1998. Methods of evaluating ruminal pH in dairy cattle. Proc. Annu. Conf. Am. Assoc. Bovine Pract. 31:203. (Abstr.)

Owens, F. N., D. S. Secrist, W. J. Hill, and D. R. Gill. 1998. Acidosis in cattle: A review. J. Anim. Sci. 76:275-286.

Reis, R. B., and D. K. Combs. 2000. Effects of increasing levels of grain supplementation on rumen environment and lactation performance of dairy cows grazing grass-legume pasture. J. Dairy Sci. 83:2888-2898.

Smith, V. R. 1941. In vivo studies of hydrogen ion concentrations in the rumen of the dairy cow. J. Dairy Sci. 24:659-665.

Underwood, W. J. 1992. Rumen lactic acidosis: Part 1. Epidemiology and pathophysiology. Compend. Contin. Educ. Pract. Vet. 14:1127-1138. 